\title{
A MERCANTILIZAÇÃO DA MAGIA NA URBANIZAÇÃO DE SÃO PAULO, 1910-1940*
}

\author{
Maria Cristina Cortez Wissenbach
}

Depto. de História - FFLCH/USP

\section{Resumo}

Com base em processo movidos contra réus incursos nos artigos que criminalizavam o curandeirismo, o espiritismo, a feitiçaria e outras práticas similares, o texto busca o significado histórico de crenças religiosas na perspectiva de um universo citadino em transformação. Contempla questões como a propagação do espiritismo, diferenças entre rituais do "baixo" e do "alto" espiritualismo e o tratamento dado ao tema pela imprensa e pelas autoridades que lideravam as campanhas antimagia.

\section{Pallavras-Chave}

Religiosidade popular • Espiritismo • Urbanização • Ritos e Crenças Afrobrasileiros • São Paulo

\section{Abstract}

Based on legal proceedings against those who practised withcraft and sorcery, spiritism, healings rituals and other practices considered as crime by the Legal Code of 1890, this article seeks the historical meannings of religious faiths in a changing urban context. The study focuses on questions such as the propagation of spiritism, the differences between "low" and "high" spiritual rituals, and the way in which these thems were treated by the press and by the leadership of the campaigns against magic.

\section{Keywords}

Popular religions • Spiritism • Urbanization - Afro-brazilian rituals and cults • São Paulo

\footnotetext{
* Este artigo é parte de uma pesquisa mais ampla, financiada pelo Capes/CNPq, que resultou na tese de doutorado Ritos de magia e sobrevivência. Sociabilidades e práticas mágico-religiosas no Brasil, 1890-1940. Departamento de História, USP, sob orientação da Profa. Dra. Maria Odila Leite da Silva Dias, 1998.
} 
"Faço milagres. Sim, faço milagres ! Mas milagres ... científicos!!" (Ariosto Palombo, ou Mahatma Patiala, ou João de Minas, Diretor da Academia Brasileira de Ciência Divina, São Paulo, 1939)

No Brasil dos primeiros anos da República, sob os auspícios de novos tempos e de um novo século que se aproximava, assistiu-se a eclosão de uma série de movimentos sociais nos quais a religiosidade popular, o misticismo e o profetismo apresentaram-se como elementos capazes de levantar as populações sertanejas. Tais foram os movimentos de Canudos, do Contestado e de Juazeiro que chegaram a abalar os alicerces do regime que se implantava e a atemorizar uma sociedade que nascia sob o signo das profundas modificações sociais e políticas ocorridas nas últimas décadas do século XIX. Fenômeno que traduziu anseios, o descontentamento e a visão de mundo de populações afastadas dos centros de modernização, o poder mobilizador das crenças religiosas não se manifestou somente nas regiões que constituíam o Brasil das áreas do interior.

Nas cidades brasileiras, sobretudo nas capitais do Sudeste, convulsionadas pelas transformações trazidas pela Abolição e pela imigração, por ritmos inusitados de crescimento populacional e de urbanização, assistiu-se igualmente uma onda de religiosidade difusa, que se manifestou sob outras formas e teve significados sociais diferenciados. Conduzido por crenças variadas e veiculado pela proliferação de práticas de cura, de adivinhação e rituais de proteção, este movimento esteve marcado por um encontro sugestivo entre antigas tradições e práticas mágicas e as correntes do pensamento espiritualista que se firmavam na época, entre elas especialmente o espiritismo que, nascido na segunda metade do século XIX, aqui rapidamente se projetou.

Na cidade de São Paulo, onde a propagação das diferentes vertentes do pensamento espiritualista por meio de rituais e de ações individuais rapidamente recebeu a designação de o comércio da ilusão, proliferaram, desde os inícios do século, consultórios de videntes, quiromantes e cartomantes que, em sua maioria, se apresentavam como madames de origem estrangeira (francesas, sírias, espanholas e ciganas, entre outras), e de curandeiros, médiuns e benzedeiras. Posteriormente, ao lado desse atendimento individualizado e ao longo do período de 1920 a 1940, surgiram também centros e institutos destinados ao tratamento de doenças para as quais a ciência médica oferecia poucas chances de cura - tuberculose, lepra, sífilis, doenças da pele, entre outros 
males - e ao desenvolvimento de novas terapêuticas para as doenças de fundo nervoso, em meio a recursos magnéticos - passes ou aparelhos - , e técnicas de exorcismo associadas ao sonambulismo e ao hipnotismo.

É difícil dar conta da extensão do fenômeno, tal a profusão de consultórios, centros e institutos que foram se formando na cidade destinados a atender uma clientela cada vez maior, ansiosa em aliviar as tensões próprias aos momentos históricos em que viviam. Na documentação criminal, no noticiário de jornais e na linguagem comum, foram, a princípio, distinguidas entre correntes e experimentações ligadas ao alto espiritismo e práticas e rituais catalogados como sendo de baixo espiritismo. Enquanto o termo alto espiritismo designava algumas das vertentes do pensamento espiritualista, especialmente o espiritismo científico ou o kardecismo, ramos do ocultismo oriental e a fenomenologia experimental do sonambulismo, do hipnotismo e do magnetismo animal, o termo baixo espiritismo era atribuído a uma multiplicidade de práticas de origens e características diversas mas, no geral, destinadas ao diagnóstico e cura das doenças do corpo e da alma e à resolução das adversidades da vida, especialmente daquelas trazidas pelo estilo de vida urbano e moderno. Práticas criminalizadas já pelo Código Penal de 1890, entre os acusados de exercer o baixo espiritismo poderiam ser encontrados curandeiros de diferentes tipos ocultistas, magnetizadores, hipnotizadores, médiuns receitistas - , benzedeiras que praticavam as simpatias da medicina mágica e do catolicismo popular e quiromantes, cartomantes e pitonisas versadas em adivinhações. E, principalmente, feiticeiros e macumbeiros, denominação que recebiam os indivíduos envolvidos nos rituais e nas crenças oriundos da população de afro-descendentes da cidade ${ }^{1}$.

De pouco adiantaram as campanhas progressivamente travadas contra os diversos tipos sociais ligados a essas práticas. Em São Paulo, nas décadas iniciadas em 1920 e em 1930, só fizeram acentuar a tendência à institucionalização de suas agremiações, fazendo aumentar progressivamente o número

\footnotetext{
${ }^{1}$ Neste sentido, a documentação básica sobre o tema são processos criminais de réus indiciados nos artigos do Código Penal de 1890 que criminalizavam o exercício ilegal da medicina (artigo 156), o uso do espiritismo, da magia e de seus sortilégios para iludir os incautos (artigo 157) e a prescrição de fórmulas medicamentosas (artigo 158). No presente artigo a documentação citada foi localizada no Arquivo do Poder Judiciário do Estado de São Paulo (no extinto Arquivo da Vila Leopoldina).
} 
daquelas registradas junto às autoridades policiais. Pressão das autoridades que demandou, igualmente, uma melhor definição das doutrinas e dos pressupostos que as norteavam: além de oferecerem lenitivos para as doenças do corpo e da alma, os dirigentes das agremiações espíritas e ocultistas passaram a buscar a comprovação empírica dos fenômenos naturais e sobrenaturais emblemáticos das teses de Mesmer e de Allan Kardec; procuraram estabelecer as distinções entre os verdadeiros espiritualistas e os charlatães e, principalmente, contestar os limites entre as ciências da aparência e o conhecimento oculto. Atestando a busca de uma racionalidade cientificista em meio a crenças espirituais, constituíam expressões de uma nova mentalidade que procurava eliminar a cisão entre magia e ciência; ou ao menos reverter o racionalismo positivista em proveito das práticas mágicas.

Pela intensidade com que se manifestou na sociedade urbana e pelas discussões mais profundas que envolveu, a presença do tema se fez notar também na literatura e na imprensa da época e entre os homens ligados aos vários ramos da ciência oficial. Os jornais, da mesma forma que destinavam espaços nas seções de anúncios para os proclamas de ocultistas sírios, de cartomantes 14 renomadas e das publicações das editoras espiritualistas, guardavam igualmente amplos espaços para noticiar, de maneira sensacionalista, as campanhas policiais movidas contra feiticeiros e bruxos. A partir de outro ponto de vista, os expoentes da medicina legal, da antropologia criminal, da psiquiatria social, os modernistas e os botânicos entre outros, observavam os transes mediúnicos e os poderes paranormais, estabeleciam as relações entre misticismo e doença mental, penetravam nas influências da música nas possessões mágicas, inventariavam o valor terapêutico das ervas da farmacopéia popular e, em linhas gerais, procuravam aprisionar tais conhecimentos e manifestações nos quadros de explicações intelectualistas e sistêmicas.

Tendo em mente o alastramento das correntes mágico-religiosas no contexto das sociedades urbanas, para os cientistas que lideravam as campanhas antimágicas, a permanência da magia e das superstições era a prova cabal da equiparação dos incautos, dos ingênuos e de seus mistificadores aos estágios mais primitivos da evolução humana. Utilizavam-se à vontade das teorias evolucionistas de Gustave Le Bon, indicando a equivalência entre a magia antiga e suas formas revividas no mundo moderno:

A magia antiga devia, ainda uma vez, reaparecer, mudando de nome sem sofrer notável modificação. Chama-se hoje ocultismo e espiritis- 
mo, os augures se denominam médiuns, os deuses inspiradores dos oráculos se intitulam espíritos, as evocações dos mortos têm o nome de materializações (Le Bon, apud César, 1939: 50-1).

E, a partir da correspondência evolutiva, adequavam a lógica dos credos então em voga às chamadas leis da magia e às do pensamento primitivo, nas formulações desenvolvidas por James Frazer e por Lucien Lévy-Brulh². Assim, por exemplo, sob a inspiração culturalista deste último, Arthur Ramos estabelecia a equiparação dos curandeiros ao shaman e ao medicine-man das tradições indígena e africana e propunha uma nova forma de abordagem ao problema social do curandeirismo pois, dentro de sua formulação, "a lógica do primitivo não pode ser idêntica à do homem branco, adulto e civilizado" (Ramos, 1931: 979).

Em particular, os representantes da psiquiatria social, membros dos institutos médico-legais que então se afirmavam, ao lado dos teólogos do catolicismo, travavam intenso debate com o espiritismo, tentando invalidar a pretensão da doutrina de Allan Kardec de se erigir enquanto categoria de verdade, cientificamente demonstrada, e focalizaram as experimentações realizadas pelos espíritas como sendo simples embustes de charlatães. Acusando também o espiritismo como um dos grandes responsáveis pelo desencadeamento da loucura, consideraram, na perspectiva dos avanços da ciência médica, os fundamentos das doutrinas mediúnicas. Já nas primeiras décadas do século XX, quando as teorias sobre a natureza das doenças mentais e sobre o inconsciente difundiam-se na Europa, os intelectuais brasileiros puderam observar as possessões mágicas e os transes na perspectiva dos ensinamentos de Charcot e de Freud. À luz dessas teorias, afirmavam que os transes nada mais eram do que estados de sugestão induzida nos quais, sob o efeito de bebidas, danças e cânticos, e de repetições monótonas, manifestava-se o inconsciente de indivíduos portadores de personalidades cindidas ou dissociadas, isto é, de esquizofrênicos - quando os incorporadores eram homens - , e de histéricas - quando

\footnotetext{
${ }^{2}$ Sobre a extensão da influência das teorias de Frazer entre etnólogos, sociólogos, historiadores, juristas e teólogos e a polêmica que se estabelecia, já nos finais do século passado, referente às relações entre ciência e magia, magia e religião, ver Gurvitch, G. (1950), esp. cap. VII, "La magie, la religion et le droit".
} 
mulheres (Ribeiro/Campos, 1931: 30 e seguintes) ${ }^{3}$. As crenças na reencarnação e na transmigração da alma - premissas centrais das correntes mediúnicas eram, por sua vez, explicadas como desejos inconscientes de regressão ao parasitismo uterino. No depoimento dado ao inquérito conduzido por Leonídio Ribeiro, afirmava Júlio Porto Carrero, catedrático de Medicina Pública da Faculdade de Direito do Rio de Janeiro:

O espiritismo, com a sua doutrina da actividade do espírito dos mortos e de reencarnação opportuna e repetida, vem ao encontro desse desejo que dorme no fundo de todos os conscientes - a ânsia pela volta ao parasitismo uterino (Carrero, apud Ribeiro/Campos, 1931: 162-63).

Também da psicanálise se retirava a correspondência evolutiva da magia à fase narcísica, quando se manifesta o princípio da onipotência das idéias, "quando o pensamento infantil julga submeter o mundo a seus desejos" (Ramos, 1932: 43) .

Amplamente debatido, o recrudescimento do espiritualismo e a propagação 16 de práticas mágicas, nos inícios do século XX, não era experiência particular à São Paulo. A imprensa paulistana faz questão de reafirmar, a todo momento e não sem uma ponta de orgulho que, sob esse aspecto em especial, compartilhava-se de características presentes nas cidades as mais modernas, modelos de nossa civilização:

Paris é considerada um expoente da civilização moderna - e, como ela, nenhuma outra grande metrópole prolifera em adivinhos, mágicos, sonâmbulos, quiromantes, ocultistas, augures e iluminados de toda a sorte. $O$ viveiro dessa classe de industriais sem matrícula é a capital orgulhosa da Europa, a ville-lumière, que é o berço do Pensamento e da Idéia (“O comércio da ilusão", Correio Paulistano, 27/05/1913).

\footnotetext{
${ }^{3}$ Correspondências similares entre os estados de transe, o sonambulismo e a histeria são encontradas no estudo pioneiro de Nina Rodrigues, publicado em 1896 na Revista Brasileira e, em 1900, na edição francesa. Nina Rodrigues, O animismo fetichista dos negros bahianos, 1935: 109.

${ }^{4} \mathrm{Na}$ raiz das formulações de Arthur Ramos - sobretudo em Os horizontes mythicos do negro na Bahia, 1932 -, encontrava-se o trabalho de Freud, Totem e tabu, especialmente parte III, Animismo, magia e a onipotência de pensamentos, de 1913.
} 
O mesmo fenômeno alastrava-se pelas demais capitais do mundo ocidental:

a epidemia ocultista grassa publicamente em Londres e Nova York, medrando à sombra dos positivismos do dólar e da libra, vicejando maravilhosamente entre as flanelas de Oxford e os algodões do Kentucky ... (idem).

Num processo de urbanização marcado pela afluência de imigrantes de várias nacionalidades, acentuava-se a feição multi-étnica de São Paulo que recebia constantemente levas de populações que mantinham as crenças da sociedade de origem. Para os contemporâneos, o comércio da ilusão era assim, em parte, explicado pela "cobiça asfixiante daqueles que os grandes transatlânticos diariamente despejam nos nossos portos" e para os quais "a crendice popular oferece-lhes palco cômodo para as suas escamoteações" ("Cartomantes e feiticeiros”, Comércio de São Paulo, 27/05/1913). No entanto, os mesmos articulistas eram obrigados a reconhecer que uma parte considerável dessas práticas era, genuinamente, de nossa responsabilidade:

Feiticeiros, porém, negros de carapinha cosmeticada dançando ao redor de um pobre Cristo mergulhado num caneco de espírito de vinho com arruda ou carobinha, é privilégio nosso, que temos nas veias um pouco do sangue dos tocadores do Congo, e muito dos costumes dos homens de yatagan recurvado, lá das bandas de Benguela ("Uma cabeleira no estomâgo. A feitiçaria em São Paulo". A Capital, 18/11/1915).

É impossível não associar este aspecto em particular da vida da cidade a um contexto marcado por rupturas e mudanças radicais, pelas crises sociais que acompanharam a história de São Paulo desta época. Pelo contrário, é possível afirmar que traduziam, numa outra linguagem, o custo social dos processos ocorridos desde os finais do século XIX, indicando as inferências que os fatos históricos - entre eles a Abolição, a República, a imigração e as novas condições de vida urbana - impingiram à organização da vida de largos contingentes populacionais. O estudo das práticas mágicas de São Paulo dos inícios do século $\mathrm{XX}$, permite que sejam desvendados fragmentos dos anseios, das expectativas e dos dramas cotidianos de uma sociedade que, ao fazer uso de concepções algumas delas seculares, demonstrava a necessidade de uma sustentação a mais para enfrentar as condições de instabilidade e de mudança presentes na época em questão. 
De outra parte, indicada pela documentação repressiva, a expansão das práticas de cura, de adivinhação e de proteção na sociedade citadina deve ser avaliada no interior de uma política disciplinar que acompanhou a urbanização e que, conforme tem sido avaliada pela historiografia social sobre as primeiras décadas da República, fazia avolumar os índices de contravenções como a embriaguez e a vadiagem (Fausto, 1984), aumentar a exclusão dos chamados demi-fou das ruas da cidade (Cunha, 1984), ou a regular o comércio da prostituição (Rago, 1991). Política que procurava coibir, na ótica da criminologia e do alienismo, os desatinos e a desordem social, vista esta como necessidade imperiosa da civilização diante da explosão urbana.

As instituições disciplinares visavam não somente as formas consideradas como as mais evidentes de desajustamento social. Conforme deixa claro Fernandes, em consonância com o processo de urbanização, passavam também a dirigir uma pressão mais drástica contra os elementos culturais que perpetuavam o estado de ignorância e incultura, herdados do passado e da mestiçagem do povo brasileiro, processo que entendiam numa ótica extremamente excludente e preconceituosa (Fernandes, 1979). Entre estes, ressaltavam aspectos 18 da cultura e da religiosidade popular, repleta de conteúdos e formas organizacionais autônomos, contra os quais se empenhou também a Igreja Católica em sua política de neutralizar as irmandades e os rituais do catolicismo popular, especialmente a partir da segunda metade do século XIX (Oliveira, 1980; Monteiro, 1978). Assim, iniciadas já nos últimos anos do século XIX e primeiros do $\mathrm{XX}$, as campanhas repressivas contra as práticas mágicas e o exercício ilegal da medicina notabilizaram-se por mobilizar diversos setores desse poder disciplinar, coadunando-se autoridades policiais, fiscais do Serviço Sanitário, representantes da Medicina Legal, psiquiatras das instituições asilares e membros da Igreja oficial. Campanhas estas que, a partir de 1928, passaram a ser coordenadas pelo Serviço de Repressão ao Baixo Espiritismo, anexo à Delegacia de Costumes ${ }^{5}$.

\footnotetext{
${ }^{5}$ Conforme o Relatório do Chefe de Polícia do Estado de São Paulo, de 1928, localizado no DAESP, tais perseguições foram conduzidas, inicialmente pelo Serviço de Inspeção dos Costumes, anexo à $2^{\mathrm{a}}$ Delegacia Auxiliar (1914), depois, pela Delegacia de Costumes e Fiscalização de Jogos do Gabinete de Investigações e Capturas (1924), e finalmente pelo Serviço de Repressão ao Baixo Espiritismo (1928), organismos que, sucessivamente, especializaram-se na repressão aos crimes em questão.
} 
Na perspectiva da história social de São Paulo desta época, o processo de urbanização, marcado por ritmos inusitados de aumento populacional, mostrouse incapaz de absorver, nos setores da economia formal, os largos contingentes atraídos pelo crescimento da cidade. E, conseqüentemente, como tem sido com freqüência apontado por Maria Odila da Silva Dias, criava formas não convencionais de sobrevivência ligadas às atividades informais, no limiar de meios considerados como infrações e crimes (Dias, 1984; Dias, 1985; Pinto, 1994). Uma primeira observação na caracterização social dos réus envolvidos nos processos criminais consultados revela que grande parte deles era constituída por indivíduos provenientes dos setores populares e remediados da sociedade que procuravam improvisar a sobrevivência ou buscar uma determinada ascensão social. Nos termos da documentação: imigrantes recém-chegados à cidade; filhos de imigrantes "ávidos por enriquecimento fácil”; homens negros que deixaram de lado seus ofícios manuais para se dedicarem inteiramente à "exploração de um centro espírita" ou dos dons de cura "há pouco tempo revelados"; viúvas encarregadas de prover o sustento do lar, versadas na leitura de cartas ou das linhas das mãos; ex-militares desmobilizados ou expulsos das suas corporações que investiam algum tempo no estudo dos fatos ocultos e sobrenaturais - homens e mulheres que, apesar da longa itinerância e da infixidez próprias à dinâmica daquele tempo, mantinham tradições culturais, fórmulas mágicas e milagrosas, crenças e fetiches que pareciam encantar uma sociedade predisposta a aceitar o que lhe era oferecido.

Uma vez estabelecidos, rapidamente formavam suas clientelas mediante informações que circulavam entre as pessoas das ruas, nas vizinhanças de bairros como o Cambuci, o Brás ou a Barra Funda, no interior de grupos étnicos ou profissionais determinados. As investigações criminais indiciaram imigrantes acusados de exercer ilegalmente a medicina junto aos grupos de sua nacionalidade de origem: o enfermeiro Carlos Stosicka que, em 1936, atendia a comunidade germânica; Schokichi Itow que, desde 1914, assistia aos imigrantes japoneses com autorização das autoridades sanitárias da época. Como aparece nos noticiários da imprensa, alguns grupos sociais elegiam também suas pitonisas prediletas, como Fortunata Barbatte, "especializada no atendimento às moçoilas da fábrica Penteado", Maria Cauwinsky, "cartomante das cozinheiras", $\mathrm{M}^{\mathrm{me}}$ Thebas, "a protegida do escol da sociedade paulistana". Mobilizando laços solidários que as adversidades da urbanização e da instabilidade acabavam por solidificar, para qualquer infortúnio haveria sempre uma determinada simpatia, qualquer desesperança poderia ser sanada com um jogo 
dos baralhos, uma leitura das mãos, com um chá, uma mezinha, um passe magnético, um transe hipnótico. E logicamente, pessoas especializadas neste tipo de atendimento.

Enquanto alguns curandeiros transformavam-se em ambulantes, como Amaro Issa, imigrante sírio que podia ser visto, em 1933, "andando pelas ruas com uma valise, contendo medicamentos e objetos da magia" (Justiça e Amaro de Almeida Issa, 1933), outros preferiam oferecer seus serviços por meio de folhetos impressos ou em anúncios publicados nos jornais da cidade. Utilizando-se de um codinome com acento afrancesado, Pedro dos Santos Boemer prometia, em 1918, receitas magnéticas para aqueles que o procurassem:

Para serdes feliz o que deveis fazer e tentar? Ide à rua Canindé, 123, ou escrevei a Pedro Casnot, com selo para resposta (Justiça e Pedro dos Santos Boemer, 1918).

As cartomantes destacavam sua origem estrangeira, a tradição da magia cigana, a ligação com o ocultismo oriental. De um cortiço da rua Bresser, pro20 pagava também Idalina Tairovitch, natural da Sérvia, "pertencente à raça cigana", seus conhecimentos mágicos utilizados no sustento do lar e de seus oito filhos, complementando os parcos rendimentos do marido, vendedor ambulante de bugigangas:

Quiromancia - Grafologia - Interessa a qualquer pessoa. Acha-se nesta bela Capital $\mathrm{M}^{\mathrm{me}}$ Naime a célebre cientista, professora de quiromancia, com sua família, que se acha residindo à Rua Bresser n. 1550. Compromete-se a fazer qualquer trabalho sobre qualquer fim. Tem viajado por diversos países da Europa, visitando as Capitais e percorrendo vários Estados do Brasil. (Justiça e Idalina Tairovich, 1939)

Outros, como é o caso do ocultista professor Baçú - Miguel Ruiz da Silva Bassuraça, brasileiro, mulato, que agia tanto em São Paulo quanto no Rio de Janeiro - preferiam anunciar aos leitores dos jornais da época seus talismãs, provenientes de seitas indianas:

Assombrosa Maravilha! 1996 curas em menos de 90 dias!! Casamentos realizados! Uma sorte grande na loteria a um possuidor dos talismãs! Últimos dias de distribuição dos pássaros Inhaburús e dos Talismãs, 
proclamava o ocultista, não sem antes advertir aos interessados de que se tratava de uma prorrogação que fazia do prazo, tendo em vista o "justo pedido da classe operária e funcionários que somente recebem seus salários e ordenados no princípio do mês" (Folheto anexo à Justiça e Bento de Paula Souza e José Furtado, 1910). Ao lado destes, curandeiros negros, como Benedito Antônio da Silva, vulgo Benedito Garfudo, limitavam-se a proclamos mais simples, ofertando: "Curas gratuitas pelos meios simpáticos, homeopáticos e cópias alopáticas" (Justiça e Benedicto Antonio da Silva, 1927).

As possibilidades de sobrevivência e em alguns casos de ascensão social dos que transformavam o comércio da ilusão em ganha-pão estavam diretamente relacionadas a uma sociedade afeita a tais apelos, ávida em solucionar por meio de recursos mágicos, fossem quais fossem, questões amorosas, insucessos econômicos, problemas familiares e principalmente a cura de doenças. Assim, confirmando o grande temor dos cientistas que lideravam as campanhas anti-mágicas, as práticas mágicas, muitas vezes provenientes das classes ínfimas da sociedade, consideradas pelos observadores como manifestações de processos de involução das camadas populares, demonstravam, no entanto, possuir uma capacidade extrema em se expandir, em contaminar e fascinar a sociedade como um todo ${ }^{6}$.

Descrevendo, em 1912, a ante-sala de um famoso ocultista de São Paulo, o articulista do Comércio de São Paulo, pôde observar:

[...] ao lado da costureirinha gentil e ingênua, em transes dubitativos sobre a fidelidade do namorado, via-se a mundana devorada pela paixão, cheia de zelos e cold-cream. A supersticiosa siciliana, de cabelos entrancados na garibaldina touca, acotovelava repetidas vezes a aristocrática representante de nosso patriciado, recendendo a ociosidade e a opopenax ("O comércio da ilusão", O Correio Paulistano, 24/09/1912).

\footnotetext{
${ }^{6}$ Segundo as teorias de Gustave Le Bon, expressa em sua obra Psychologia das multidões, um dos autores mais citados nos inquéritos da época, a degeneração era uma ameaça social pois continha os germes da contaminação, podendo fazer com que a multidão, mediante sugestão quase que hipnótica, regredisse a um estágio atávico e primitivo. Aspecto indicado pela leitura do trabalho de Dain Borges, 'Puffy, Ugly, Slothful and Inert': Degeneration in Brazilian Social Thought, 1880-1940, 1993: 237.
} 
Às portas do templo da rua Guarani, onde atendia o quiromante professor Schiloch e oferecia aos consulentes as maravilhosas pedras de Cevar, provenientes do Sudão, que emprestavam vigor e energia aos seus possuidores, o jornalista via chegar não só os indivíduos oriundos das "ínfimas camadas, onde a instrução ainda não penetrou”, como também representantes das classes abastadas da cidade:

Não eram somente os bondes que ali vazavam a população rude e inculta; também os automóveis e as carruagens particulares tomavam com freqüência o caminho da Cabala, em procura de um pouco desta Ilusão, sem a qual a vida não seria possível. (Idem).

Cidade de múltiplas etnias, onde se mesclavam línguas e tradições culturais diversas, em que se procurava a todo custo improvisar meios de obter sobrevivência, a proliferação das práticas mágicas relaciona-se à chegada de levas de imigrantes das mais variadas nacionalidades. Os credos de suas culturas de origem vinham se acrescentar a um caudal de tradições fortemente arrai-

22 gadas na sociedade brasileira, provenientes das crenças africanas e das fórmulas da magia ibérica e indígena.

Liana Trindade, ao estudar a religiosidade popular na cidade de São Paulo dos inícios do século, pôde estabelecer a presença de cinco vertentes às quais se encontrariam referidos os credos em voga: as correntes do ocultismo, magnetismo e esoterismo; centros espíritas kardecistas; curandeiros, benzedores e milagreiros; a magia européia; os cultos africanos, entre eles especialmente a macumba (Trindade, 1991: 164-173). No entanto, conforme ela própria assinala, a magia urbana esteve marcada por sucessivos processos de sincretismo, entendidos como reelaborações culturais e religiosas ocorridas diante das condições peculiares da cidade na época; no seu dizer, construções míticas que foram se moldando aos diversos contextos presentes na história da cidade do século XVIII às épocas mais recentes. Desta maneira, nos processos criminais aqui indicados, nas acusações de práticas de baixo espiritismo estão presentes - sob o crivo das autoridades e enredados por preconceitos - simbologias, técnicas de cura e rituais retirados das várias correntes.

Afirmada pelos estudiosos das tradições religiosas brasileiras, os movimentos sincréticos dominavam a feição da magia urbana (Bastide, 1983). Em dinâmicas que se orientavam nas mais diferentes direções: crenças afro-brasileiras ou de origem banto que se aproximavam do espiritismo; combinações 
entre as tradições da magia européia e as simpatias das benzedeiras do mundo rural; do próprio espiritismo com as formas que lhe deram origem - do hipnotismo, do sonambulismo clarividente e do magnetismo animal, ou mesmo com o ocultismo de origem oriental. Nada mais compreensível se for considerado o ecletismo da magia, sua atenção na eficácia e, sobretudo, levandose em conta o processo de mercantilização que ocorreu no mundo urbano desta época. Nada mais revelador, também, do que o caso relatado por Oswaldo Xidieh sobre o marceneiro italiano que, uma vez estabelecido em Mogi das Cruzes nas primeiras décadas do século XX, rapidamente transformou sua produção de bonecos de madeiras em imagens para os rituais afro-brasileiros, realizando, conforme denota o título de seu artigo, uma fusão entre elementos ítalo-brasileiro-africanos (Xidieh, 1944). Envolvendo na maior parte das vezes crenças não cristalizadas, as práticas mágicas enquanto espaços reveladores das experiências sociais dos setores pobres e remediados da sociedade no contexto da urbanização traduzem, acima de tudo, um amplo movimento de readequações, de re-significações e de trocas.

Alguns processos criminais consultados são exemplares para ilustrar esse aspecto pois que envolviam, já na década de 1930, centros espíritas que, a pretexto de não possuírem licença, foram investigados em razão da condição social e étnica de seus integrantes. Em 1931, foi acusado textualmente de praticar bruxarias, Amaro Cardoso, diretor do Centro Espírita Sociedade Democrática Maria Caridade, estabelecido no Cambuci e com filiados em sua maioria provenientes dos setores negros da população, como informam as testemunhas do caso:

"que pode afirmar que a casa de Amaro é freqüentada somente por homens e mulheres de cor preta, os quais ali faziam com Amaro cenas que surpreendiam a depoente ..." (Justiça e Amaro Cardoso, 1931).

Das descrições infere-se que o acusado praticava rituais que combinavam passes magnéticos e fórmulas de exorcismo para o combate de feitiços. A presença de espíritos invocados justificava, por outro lado, junto aos pontos de riscado, o uso de pólvora e de facas de ponta para proteção dos participantes da reunião: "que é verdade que, durante suas sessões, costuma fincar punhais nas paredes que circundam o Centro, para evitar que seus associados sejam vitimas da magia negra" (Justiça e Amaro Cardoso, 1931).

Embora fato ainda não explicitado no contexto das investigações criminais, trata-se provavelmente de centros nos quais se realizava o encontro entre os 
elementos do espiritismo e as crenças afro-brasileiras, do qual se originariam as vertentes da umbanda e da quimbanda (Trindade, 1991: esp. parte V). Assim, revelando tendências mais amplas, a mesma mescla se encontra presente no Centro Espírita Na. Sra. da Aparecida, onde atendia Francelino Inácio da Silva, preto, sapateiro, chamado pelos filiados de Pai Francelino, acusado de "aliar a religião, o espiritismo e a macumba" e de ser homem ignorante. Especializado, segundo ele próprio declarou, "no tratamento de mordidas de cobras, males da cabeça, feridas bravas", atendia sobretudo "clientes que se apresentavam com o corpo desacorsoado, com doenças que o acusado identificava como mal contraído" (Justiça e Francellino Ignácio da Silva, 1939). Numa direção diferenciada, no Centro Espírita São Miguel Arcanjo, José Francisco do Monte, ex-militar, coadjuvado por sua mulher, dedicava-se à leitura da sorte em uma bola de cristal e recebia seus consulentes vestido com um quimono roxo, desenhado com sinais cabalísticos, segundo informam as autoridades policiais: “onde se nota o sol, a lua e as estrelas" (Justiça e José Francisco do Monte, 1933).

O exemplo mais esclarecedor precede no tempo os acima referidos e diz respeito às ações de Bento de Paula Souza, curandeiro negro-ocultista-espírita, 24 indiciado em 1910 (Justiça e Bento de Paula Souza, 1910; Trindade, 1991: 147150; Koguruma, 2001: 139). Proveniente do Rio de Janeiro, ex-tipógrafo e excombatente das forças patrióticas do marechal Hermes da Fonseca, Paula Souza estabeleceu na cidade uma entidade denominada Grêmio Ocultista de São Paulo, da qual constavam, entre outros objetivos, o de "fazer uso das ciências ocultas, de realizar sessões do espiritismo científico e psiquismo", de promover escolas para a educação cristã, de fornecer tratamento para os obsedados, consultas mediúnicas e, por fim, "impedir as desavenças desavergonhadas nas famílias". A esses objetivos heterogêneos coadunavam suas práticas de curandeirismo, nas quais se evidenciam explicitamente os elementos de religiosidade negra, provavelmente relacionados à macumba, florescente tanto no Rio de Janeiro quanto em São Paulo. Elementos que haviam sido indicados não só pelos objetos e fetiches encontrados em sua casa, como também pelas descrições de seus procedimentos, feitas pelas testemunhas. Utilizando-se de uma valise que o acompanhava quando atendia à domicílio,

de dentro retirou um rosário grande, três facas de ponta, um pedaço de giz e outros objetos [...] e com eles dizia algumas coisas que a depoente não entendia por serem ditas em língua de Congo, conforme ele próprio declarava, 
afirmava Maria Isabel Siqueira de Figueiredo, que colocou sob seus cuidados uma filha que padecia de "ataques desde os sete anos". Diante das pressões das autoridades policiais, afirmava ainda a testemunha, de nacionalidade portuguesa, que "não pode classificar as práticas a que já se referiu, mesmo porque a depoente nunca viu iguais"; estranheza em que depositava suas esperanças, depois de haver passado por quase todos os curandeiros de São Paulo e de Santos.

No encontro de credos, de correntes e de simbologias revelado pela documentação, o espiritismo aparece como elemento catalisador. A influência considerável que exercia é repetidamente assinalada pelos estudos feitos na época.

Não é possível pegar a feição de nossa gente, conhecer a moral e a reles formação espiritual dela, pondo de parte os centros onde se ensina e se pratica a doutrina que, sobretudo nas cidades, exerce sobre o povo a ascendência do baixo catolicismo supersticioso e macumbeiro de tempos atrás,

considerava Antônio de Alcântara Machado, num inquérito realizado em 1930 sobre o que ele qualificava como sendo o comércio e a indústria do espiritismo no Estado de São Paulo (Machado apud Ribeiro e Campos 1931: 126). Neste mesmo inquérito, avaliou os números que indicavam tal expansão: em menos de um ano, de outubro de 1929 a junho de 1930, haviam sido legalizados junto às autoridades policiais do Estado cerca de 20 centros espíritas, crescimento que se manteve na mesma razão, no período subseqüente de julho de 1930 a setembro de 31, conforme continua Leonídio Ribeiro.

De outra parte, analisando os estatutos anexados aos processos de legalização dessas agremiações, Alcântara Machado fez questão de destacar, em passagens irônicas, o semi-analfabetismo de seus redatores e a confusão de doutrinas aí apresentadas. Diante do fato generalizado, concluiu sua investigação, afirmando que "a pajelança está sendo desbancada pelo espiritismo". Fato indicativo nos processos criminais, é preciso notar que muitas das agremiações que se legitimavam como centros espíritas apresentavam de fato outras tradições que, possivelmente buscavam proteção sob o rótulo do espiritismo. Neste sentido, usando dos próprios termos de Alcântara Machado, é possível afirmar que a pajelança e o catolicismo popular imiscuíam-se no interior dos centros espíritas.

A história do espiritismo no Brasil esteve marcada por um lento processo de legitimação junto aos órgãos oficiais, sobretudo nas batalhas travadas nos fóruns do Rio de Janeiro por juristas renomados como Viveiros de Castro e 
Macedo Soares (Maggie, 1992; Machado, 1983). ${ }^{7}$ Mediante o seu reconhecimento enquanto religião, os defensores do espiritismo esperavam abrandar as disposições do artigo 157 do Código Criminal de 1890 que, textualmente, criminalizava as práticas do espiritismo. E, em contraposição, fazer valer os direitos constitucionais previstos no artigo 72 da Constituição da República, que determinava a liberdade de cultos. Incongruências do novo regime também freqüentemente notadas pelos setores populares nos seus embates com as autoridades públicas; em nome da liberdade de culto agiam os profissionais ligados aos vários ramos do comércio da ilusão; em nome das reformas educacionais apelavam também para contestar a não validade de seus títulos, nas acusações de exercício ilegal das profissões: “- E a lei Rivadávia, meu caro senhor, [...] se é questão de diploma, amanhã lhe apresentarei um”, dizia, em 1913, a espanhola $\mathrm{M}^{\mathrm{me}}$ Carmem, cartomante e parteira nas horas vagas, ao delegado Cantinho Filho, referindo-se à reforma Rivadávia Corrêa que havia retirado o ensino profissionalizante da tutela pública, fazendo proliferar institutos particulares ("O comércio da ilusão", O Comércio de São Paulo, 19/06/1913).

No entanto, imaginar uma pureza doutrinária ou fidelidade às premissas espíritas compartilhada entre os inúmeros centros que se formavam, é ignorar a feição aberta da doutrina espírita e a dinâmica que as tradições da religiosidade popular tomavam na época. Segundo colocam os estudiosos do assunto, o espiritismo apresentava-se, a um tempo, como religião, filosofia e ciência, aliando essa feição doutrinária a propostas pragmáticas voltadas à caridade cristã, à formação de entidades que tinham muito em comum com as sociedades de auxílio mútuo dos inícios da industrialização, orientadas ao atendimento, nos hospitais e nas curas mediúnicas, dos setores desprotegidos da sociedade urbana (Ferreira, 1973: esp. parte IV). Filosofia, religião e ciência, o espiritismo embora considerado herético pelas bulas papais e pelas pastorais dos bispos brasileiros, não se colocava frontalmente contra as tradições do catolicismo profundamente enraizadas nas populações brasileiras e nos imigrantes latinos,

\footnotetext{
${ }^{7}$ De acordo com Yvonne Maggie (em Medo do feitiço) e Ubiratan Machado (em Os intelectuais e o espiritismo) tratava-se de um movimento que procurava, de fato, isolar do chamado espiritismo científico as práticas consideradas como sendo próprias ao baixo espiritismo. Além disso ambos defendem a tese de que os artigos do Código de 1890, especialmente o art. 157, em seus sub-textos, denotavam o endosso às crenças pois partiam do reconhecimento e da aceitação da eficácia e do poder que tinham as práticas da magia em curar e seduzir aqueles que as procuravam.
} 
propondo antes uma convivência pacífica ${ }^{8}$ Finalmente, diante das demais correntes religiosas do contexto brasileiro, o espiritismo guardava também elementos em comum: a possibilidade de comunicação direta com as entidades sobrenaturais por meio da mediunidade e dos transes, a crença na imortalidade da alma, a utilização de magnetismos para os processos de diagnóstico e exorcismo dos infortúnios e das doenças - núcleos em comum que possibilitavam as aproximações.

Defendido nos inícios do século pelos expoentes da ideologia positivista, em nome da liberdade de cultos, das religiões e do exercício profissional, o espiritismo agiu rapidamente entre os setores médios das populações urbanas. A penetração na classe média veio tanto de sua proposta cientificista quanto das experiências e demonstrações públicas que freqüentemente eram realizadas, no Brasil, na França e nos Estados Unidos, para a comprovação da veracidade de suas crenças. Com esse discurso cientificista, o espiritismo realiza amplas conversões entre intelectuais, médicos, funcionários públicos e militares, alguns deles já anteriormente convertidos ao positivismo? .

De fato, pouco importava se a comunidade científica e católica teimasse em contestar meticulosamente cada uma dessas experimentações, pois conforme aponta Keith Thomas, uma vez aceitas, as crenças religiosas prescindem de comprovação, passando a ter uma qualidade autoconfirmatória indiscutível e inabalável (Thomas, 1991: 522). Tendo em vista a mentalidade do homem desta época, é impossível minimizar os efeitos de reclamos que prometiam a equiparação de fenômenos míticos a procedimentos científicos: "Faço milagres. Sim! faço milagres! Mas milagres ... científicos!!”, expressava um ocultista que agia em São Paulo, desenvolvendo seus poderes em "sessões espíritas ao sistema indiano e não kardecista”, recebendo ondas magnéticas ema-

\footnotetext{
${ }^{8}$ Neste sentido, no contexto das doutrinas espíritas no Brasil, prevaleceram as vertentes preconizadas por Roustaing que, aliando os ensinamentos de Alan Kardec ao texto do Evangelho, enfatizava a configuração de um espiritismo evangélico-católico. Sobre Roustaing e sua influência sobretudo no pensamento de Bezerra de Menezes - um dos principais teóricos do espiritismo brasileiro - ver: Hess, David. The Many Rooms of Spiritism in Brazil, 1987; Warren, Donald. A terapia espírita no Rio de Janeiro por volta de 1900, 1984.

${ }^{9}$ Entre as conversões à nova religião, junto à comunidade científica internacional, os estudiosos do espiritismo ressaltam a de César Lombroso, teórico da Antropologia Criminal que aqui fez escola. César Lombroso, Hipnotismo e mediunidade, 1975.
} 
nadas do "Santuário Violeta, Terceira Montanha, Hymalaia, Índias Inglesas", e onde havia recebido o grau de Mahatma (Justiça e Ariosto Palombo, vulgo João de Minas e outros, 1939).

De outra parte, a penetração do espiritismo nas camadas populares - e portanto, como diriam os espíritas científicos, sua conversão em práticas do baixo espiritismo - veio, sem dúvida, do ecletismo de sua doutrina que permitia adequações às tradições religiosas da cultura popular. Mas, principalmente, conforme apontam os estudiosos do assunto, o elemento responsável pelo sucesso do espiritismo esteve localizado não em sua ênfase intelectualista mas na prática taumatúrgica dos médiuns curadores (Damazio, 1994: 152-4; Trindade, 1991: 142; Hess, 1987: 19-21; Warren, 1984). Acoplando-se à figura dos curandeiros em conversões reais ou aproximadas, a prática de cura dos médiuns ia ao encontro dos anseios de uma sociedade profundamente atordoada por um mundo em transformação, mas nem por isso capaz de responder as angústias criadas por ele mesmo.

Se uma parte dos trabalhos feitos junto aos homens da magia destinou-se à endireitar vidas atrapalhadas, grande parte dos que procuravam os curandeiros, magnetizadores, ocultistas e espíritas buscavam as práticas da medicina espiritualista e da cura mediúnica, afligidos pelos males físicos para os quais a ciência médica não encontrava solução. Diante de diagnósticos médicos conclusivos em doenças como a sífilis, a tuberculose, a lepra, ou mesmo frente à incapacidade da ciência de minimizar a ação das epidemias que com freqüência grassavam nas cidades, a população urbana continuava a preferir as concepções mágicas das doenças e dos infortúnios, atribuindo-os à depurações vindas dos céus, à feitiçaria, à encostos, ao mau-olhado, à ação de espíritos que obsedavam os mortais e, portanto, vistos como males que seriam diagnosticados pela clarividência de médiuns ou de incorporadores e por eles exor$\operatorname{cizados}^{10}$. Além do mais, a própria linguagem da medicina oficial poderia ser também traduzida em códigos fetichistas, reelaborados pelos setores sociais que dela faziam uso. Muitas vezes, diante da linguagem hermética dos diag-

\footnotetext{
${ }^{10}$ Entre os males exorcizados pelos médiuns curadores, sobressaíam-se as doenças chamadas de fundo nervoso, consideradas como estado mórbido induzido por ação fluídica de influências estranhas, inteligentes, segundo Adolpho Bezerra de Menezes, em sua obra de 1893, A loucura sob um novo prisma: estudo psiquico-fisiológico, cf. Donald Warren, A terapia espírita no Rio de Janeiro por volta de 1900, 1984. Concepções de doenças e de males próximos, sem dúvida, das visões de africanos e afro-descendentes.
} 
nósticos médicos, os leigos transformavam os resultados dos exames em sinais mágicos: "que os médicos dizem que ele tem três cruzes", explicava Jorge José, tuberculoso e sifilítico, não só sua doença como também, homem marcado por tais sinais, sua predestinação e sua conversão às artes da quiromancia (Justiça e Jorge José, 1939).

Enquanto o espiritismo agia como elemento agregador das diversas correntes da magia urbana, um grande poder continuava a emanar do feitiço negro, estivesse ou não protegido sob a capa dos centros espíritas. Por isso mesmo, tendo em vista o temor e o preconceito que circundavam as avaliações de seus rituais, a maior parte das acusações registradas nos processos criminais incidia sobre os setores negros e mestiços que se dedicavam ao que era qualificado como baixo espiritismo. Aliás, para o curandeiro negro de pouca valia representava o simulacro espírita, legalizado ou não. O critério que norteava as investigações dos centros era absolutamente discricionário, conforme revela o texto dos relatórios dos chefes da polícia da época. Em 1928, relatava-se:

"foram fechados vários centros espíritas onde se verificou não ser o seu intuito a caridade, mas sim o aproveitamento da ignorância dos incautos que os freqüentavam. Na concessão de licenças para a organização de centros espíritas foi adotado o critério de estudar e investigar não só a moralidade senão também a capacidade intelectual dos seus dirigentes" (Relatório do Chefe de Polícia, 1928).

O viés discriminatório duplicava-se quando se tratava de investigar ou noticiar as ações de curandeiros negros; sinônimo de baixo espiritismo, eram estes, no geral, aprioristicamente chamados de feiticeiros e macumbeiros; seus rituais eram rapidamente associados a festivais de depravações e de lascividade e as descrições de suas moradias e de seus locais de atendimento, enfatizavam nítida e ironicamente o primitivismo dos objetos rituais e seus odores:

O feiticeiro habitava o último cômodo desse grande cortiço [na Rua dos Imigrantes]. O seu cubículo estava repleto de raízes, ervas em confusão, peles de víboras, cornos de boi, de carneiros e de cabras, couros de lagarto, de jibóia, um turbilhão de ossos, um fêmur inteiro, uma tíbia partida, fragmentos de ossos humanos, um crânio solto, dois maxilares desdentados, guizos de cascavel, tranças louras, negras e castanhas, um chumaço encarapinhado, dentes esparsos... 
tudo isso sendo observado por: "um S. Onofre, de braços cruzados, metido num boião de banha" ("O comércio da ilusão. Cartomantes e feiticeiros", O Comércio de São Paulo, 27/05/1913).

De fato, porém, embora avessa a qualquer conotação intelectualista ou cientificista, evocando crenças afro-brasileiras vindas do passado escravista, a magia dos negros exercia uma atração sem medidas. No levantamento feito por Maynard Araújo sobre abusões populares, o homem negro, na cultura popular e na medicina mágica do Vale do Paraíba, é visto por excelência como um homem mágico (Araújo, 1958). Dos que portam em sua bagagem cultural amuletos e rituais de cura, de proteção e também de malefícios, ele é também o mais temido. Seus talismãs exercem um efeito considerável. Permanecem intocados até hoje, após mais de meio século, em envelopes lacrados e anexados aos processos criminais; as autoridades judiciárias não ousaram examinar a prova que constava dos autos, limitando-se a ler as descrições feitas pelos escrivães policiais: "composto de um pedaço de gesso com inscrições, uma figa, um cavalo marinho, dois guizos de cobra, objetos que se acham misturados com um pó cinza". (Justiça e Maria Aurora, 1939). Os pesquisadores também 30 souberam respeitar os lacres que os protegem de possíveis efeitos. No interior dos patuás podem ser encontradas rezas ou orações protetoras, que revelam a violência que se mantinha acoplada à vida dos setores negros da população. Poderosas são também suas infusões, preparadas com ervas e produtos da farmacopéia popular, que dominam com destreza.

Esse poder que emana dos feiticeiros, e sobre o qual a documentação da época fez questão de pontuar, advém da força de crenças e de rituais seculares numa sociedade aparentemente convertida aos argumentos cientificistas. Para setores da clientela que buscam suas estratégias de cura, de feitiço e de contrafeitiço, ou a ação protetora de seus patuás, talismãs e amuletos, são eles por vezes o último recurso, talvez o mais poderoso entre as fórmulas de magia existentes. A imagem mítica do homem negro na posse de poderes ocultos seduz também os imigrantes recém-chegados, que vislumbram, por detrás de uma certa estranheza que sentem, ilimitadas possibilidades.

Embora os sinais do passado escravista tenham sido pulverizados pela penetração vertiginosa de imigrantes; embora muitas das tradições culturais e sociais dos negros paulistas possam ter se diluído na convivência entre eles e os estrangeiros, compartilhando os mesmos cortiços e os mesmos bairros de São Paulo, manteve-se aparentemente íntegra a força de sua magia. As práticas sociais da magia facultavam aos homens negros espaços de reconheci- 
mento num universo social que acima de tudo os discriminava. Respeitados como indivíduos portadores de atributos mágicos, as causas deste prestígio devem ser consideradas sob a perspectiva de um passado de exploração que, para o bem ou para o mal, havia exacerbado a utilização de artifícios variados na luta contra a dominação escravista. Provavelmente guardava-se na memória, dos tempos não muito longínquos, as histórias dos enfeitiçamentos praticados pelos negros escravos contra seus algozes. Num artigo sobre a feitiçaria negra, Arthur Ramos remarcou os complexos processos cognitivos entranhados nos envenenamentos causados por escravos, demonstrando que por detrás de cada uma das poções disponíveis, encontrava-se a escolha de agonias diferenciadas. Entre as ervas utilizadas existia uma predileção pelo pipi ou titi, chamada também de herva da Guiné ou de amansa senhor, pois caracterizava-se por uma ação insidiosa e lenta, causando estados de letargia que precediam a morte. Além disso, acreditando no ordálio africano de que "se o veneno age, é unicamente porque a vitima terá sido condenada", os escravos transferiam o julgamento final de seus atos às entidades que eram por eles evocadas (Ramos, 1935). Os procedimentos religiosos e mágicos, independentemente de suas origens, pressupunham aprendizados e escolhas muito mais profundas, plenos de significados sociais.

O espaço da magia como possibilidade de projeção de individualidades oprimidas estendia-se em direção a outros setores sobre os quais incidiam o preconceito, o descrédito e a moralidade estreita da sociedade da época: ciganos, portadores de defeitos físicos, doentes estigmatizados e, sobretudo mulheres. As mulheres transformavam também os espaços das práticas mágicas em experiências libertadoras, entendidas como desforras: "se a mulher é um ser impotente e passivo no domínio da religião, ela se vinga no domínio da magia, onde é particularmente apta às obras da feitiçaria", dizem os etnólogos (Aragão, 1980). Ou, como já sinalizavam os observadores da época, criavase nessas esferas a possibilidade da vingança de Eva. Ao contrário do que ocorria, por exemplo, na hierarquia eclesiástica do catolicismo, tanto no espiritismo quanto nos demais cultos de possessão, as mulheres passaram a exercer um papel incontestável: dirigindo centros espíritas, chefiando as largas comunidades do candomblé, recebendo santos ou incorporando os espíritos, a figura feminina projetava-se e expunha suas qualidades sensitivas e de liderança nos domínios da espiritualidade, mesmo que estas estivessem contidas nos marcos de sua vida doméstica e rotineira. 
Entre as que se dedicavam à arte de curar, as peças criminais destacaram a figura das benzedeiras que, tal como os curandeiros negros, estabeleciam linhas de continuidade com as tradições da medicina mágica e do catolicismo popular da história colonial e imperial brasileira. Florestan Fernandes pontuou a complexidade dos poderes e dons das benzedeiras que escondiam, sob uma aparente simplicidade e domesticidade, uma arte conduzida por fórmulas especiais, evocações e exorcismos advindos de um saber transmitido em gerações de linhagens femininas (Fernandes, 1979: 344-46). Na cultura popular e na sociedade da época foram conhecidas pela eficácia de seus benzimentos e simpatias para determinados males: ninguém melhor do que elas para a cura de dores de cabeça e doenças infantis ocasionadas por quebrantos ou mau olhado, e sobretudo para as bicheiras. Também reconhecia-se o poder de suas infusões, e por isso mesmo eram por vezes descritas à imagem das bruxas medievais, com seus grandes caldeirões: "que Rosalina tem um grande caldeirão, onde prepara um caldo com ossos diversos, que o caldo é vendido aos mesmos doentes", descreviam as testemunhas sobre os preparados da espanhola Rosinha Maior que, além destes, administrava a seus pacientes outros métodos de cura: "que outros doentes ela declarante tem curado com rezas e salivas, pois tem o poder de curar com sua própria saliva a doentes acometidos de moléstias de somenos gravidade" (Justiça e Rosinha Cinero Carrion Mayor, 1927; 1931).

Numa sociedade marcada por concepções morais estreitas, que aprisionavam as mulheres em papéis sociais pré-determinados e rígidos, e impregnada pela idéia de culpa e de pecado vinda da tradição judaico-cristã, as pitonisas exerciam uma ação social positiva. $\mathrm{O}$ afluxo aos consultórios das videntes de pessoas das mais variadas camadas e a projeção que muitas delas conquistaram no mundo urbano revelam mecanismos liberadores das amarras do tradicionalismo social.
A feiticeira só poderá ser substituída por outra feiticeira, porque os desa- bafos que a sociedade levava confiantemente áquela e levará à que lhe vier tomar o lugar em nada se parecem com o assunto das sagradas confissões da Igreja,

observava um articulista no elogio fúnebre dedicado à $\mathrm{M}^{\mathrm{me}}$ Zizinha - Hermínia de Lacerda Nascimento Câmara - célebre pitonisa do Rio de Janeiro, pertencente à conhecida família da sociedade carioca, mas, conforme lembra o mesmo, portadora de um defeito físico desde a infância que, segundo ele, procurou compensar com os estudos ocultistas (Oscar Lopes, "Necrológio a 
Mme. Zizinha", O País, 5/12/1915). Nos consultórios das cartomantes e das quiromantes, as cartas e as linhas da mão colocavam-se como mediações que revelavam o íntimo das almas de pecadores, pretextos de confissões alternativas nas quais homens e mulheres podiam relatar suas pequenas e grandes faltas, seus casos amorosos e seus defeitos, livres de qualquer pré-julgamento.

Nicolau Sevcenko, em seu estudo sobre a São Paulo dos anos vinte, projetou numa imagem sensível o impacto de processos históricos vertiginosos sobre os habitantes da cidade:

Essa cidade que brotou súbita e inexplicavelmente, como um colossal cogumelo depois da chuva, era um enigma para seus próprios habitantes, perplexos, tentando entendê-lo como podiam, enquanto lutavam para não serem devorados (Sevcenko, 1992: 21).

No contexto de um mundo em ebulição, cadenciado por uma relação ambivalente entre adversidades e promessas de progresso, em que o olhar do imigrante desgarrado e o do homem negro esgarçado dos laços escravistas só poderiam focar o futuro, a diversidade de formas e o conteúdo mesmo da magia, tal como esteve configurada nesta época, devem ser igualmente referidos às exigências que eram impostas pela economia de mercado, pelo mundo da concorrência e pela indústria.

Conforme deixaram claro em seus depoimentos, para os homens deste tempo a aproximação a qualquer uma das correntes então em voga, o pertencimento a centros espíritas ou a institutos esotéricos deveria se traduzir em resultados diretos e imediatos, objetivando-se o conteúdo transformador aí proposto como ferramenta capaz de protegê-los da ameaça de serem devorados. Tendo em vista a concorrência desleal que era imposta por uma economia instável, as vicissitudes da vida, averbadas na percepção que faziam das causas dos infortúnios, eram, quase sempre, projetadas no outro. Dos conflitos amorosos - casos não resolvidos, desarranjos de lares - aos insucessos profissionais ou financeiros, as suas vidas atrapalhadas eram vaticinadas à inveja alheia, ao mau-olhado, a feitiços feitos por adversários ou rivais. A luta pela sobrevivência - questão que se colocou em última instância na interpretação das práticas mágicas - implicava também em vencer a concorrência, projetandose individualmente através, quem sabe, das fórmulas de sucesso que eram oferecidas pelo comércio da ilusão. 
A modernidade, palavra-fetiche que encerra um universo de evocações no dizer de Sevcenko, esteve acompanhada pela instalação de institutos espiritualistas, ocultistas e de magnetização, como o Instituto Humanitário de Radiação Mental (1937), a Academia Brasileira de Ciência Divina (1939), o Grêmio Ocultista de São Paulo (1910), a União Beneficiente Espiritualista (1939), a Cruzada de Reavivamento Moral. Nestes locais desenvolviam-se cursos que prometiam o acesso aos Segredos de Rasputin, e aos dos Faraós, às receitas de como desenvolver o magnetismo latente em cada um dos assistentes e, desta maneira, poder "atuar diretamente sobre as pessoas [...] dominando-as por tal maneira, a torna-las verdadeiras escravas de nossa vontade", conforme o folheto Segredos da Magia, de autoria de Pedro Casnot (Justiça e Pedro dos Santos Boemer, 1918).

De outra parte, a pedagogia que conduzia estes cursos adequava-se igualmente aos ritmos da modernidade: "racionalmente práticos, com um ensino nu, rápido, sem palavras difíceis e complicações cabalísticas”, em que seriam divulgados, entre outros, os ensinamentos de um "ocultismo vital, biológico, científico, o ocultismo-alavanca para se vencer na vida terrestre" (Justiça e Ariosto Palombo e outros, 1939). Ensinamentos estes que poderiam ser complementados em conferências ou leitura das publicações da editora $\mathrm{O}$ Pensamento, prolixa em títulos até os dias de hoje: A vida triunfante, O homem completo, O caminho da iniciação, Regras para o viajar etc. ${ }^{11}$. Além do almanaque $O$ Pensamento que acompanhava o homem urbano nas rotinas do dia-a-dia, poder-se-ia acessar, na Emissora de Rádio Esotérica, projeto de Ariosto Palombo, ondas magnéticas que do longínquo Oriente trariam aos ouvintes Fortuna, Harmonia, Paz, Saúde, Felicidade e Juventude.

Ao lado da divulgação dos ramos alternativos da ciência médica, especialmente da homeopatia e da medicina naturalista, que realizavam amplas aproximações às receitas da farmacopéia popular, surgiam também terapêuticas renovadas que propagavam os cuidados com o corpo, com a alimentação e com o clima, como por exemplo aqueles difundidos pelo Instituto Psicote-

\footnotetext{
${ }^{11}$ Além dos títulos mencionados, a editora O Pensamento, de São Paulo, contribuía também com a divulgação das chamadas ciências ocultas, em publicações como: Magnetismo e hypnotismo (1940); Radiopatia, ciências herméticas e psicologia experimental; Dicionário de sciências occultas (1937); Fisiognomia e frenologia; Os mystérios da maçonaria e das sociedades secretas (1937), entre outras.
} 
rápico Salus, de Francisco Fritelli (1930), ou pelo sistema, batizado por Moura Lacerda, de "Autocura Física de Piroterapia Brasileira”. Dizendo-se professor higienista, Moura Lacerda ensinava aos que o procuravam "os meios para se livrarem dos males físicos que os afligem, recomendando-lhes sol, ginástica, regimens alimentares, curas por clima e chás de plantas comuns" (Justiça e Francisco Xavier Galvão de Moura Lacerda, 1930). Além da divulgação dos esportes, da ginástica e dos espetáculos públicos, a nova sensibilidade em relação ao corpo vinha inscrita também em novas maneiras de tratá-lo (Sevcenko, 1992: esp. cap. 1).

Cursos, conferências, leituras, atendimentos individuais e filiação aos institutos conformavam algumas das múltiplas alternativas que poder-se-ia encontrar difundidas na cidade, para se aperfeiçoar diante das exigências que eram feitas pelo mundo urbano. $\mathrm{O}$ ritmo da cidade e as pressões multivariadas produziam, uma sociedade nervosa, sensível e atenta aos temas relacionados ao psiquismo. Uma parte das ações desenvolvidas e catalogadas como sendo de exercício ilegal da medicina ou de uso da magia envolveu indivíduos que se diziam psiquistas e se especializavam no tratamento das doenças nervosas, por meio de novas terapêuticas a elas associadas. Em 1938, Ítalo Benassi era investigado por oferecer "tratamentos para psicoses comuns e espiritóides, fobias, tics nervosos, desânimo, gagueira, vícios e embriaguez", por meio de métodos igualmente numerosos: "sugestão, magnetismo, hipnotismo, clarividência sonambúlica, receitas de banhos com guiné, arruda, alecrim, saco-saco, dentes de alho etc" (Justiça e Ítalo Benassi e outros, 1938). Também as teorias psicanalíticas que aqui se difundiram de maneira tardia, poderiam se popularizar na forma de exercícios destinados a ensinar o homem moderno a "maneira como deve respirar, pensar e [...] dialeticamente viver" (Justiça e Amandus Quart Siloe Schoen, 1931). Nos marcos da cidade das primeiras décadas do século, magia e ciência gravitavam por vezes em círculos concêntricos, em torno de procedimentos e crenças similares.

\section{Fontes e Referências Bibliográficas}

\section{Processos criminais. Arquivo do Poder Judiciário do Estado de São Paulo (Ar- quivo da Vila Leopoldina)}

1910. A Justiça Pública, autora; Bento de Paula Souza e José Furtado, indiciados. 1918. A Justiça Pública, autora; Pedro dos Santos Boemer, indiciado. 
1927. A Justiça Pública, autora; Benedicto Antônio da Silva, indiciado.

1927 / 1931. A Justiça Pública, autora; Rosalina Cinero Carrion Mayor, vulgo Rosinha Maior, indiciada.

1930. A Justiça Pública, autora; Francisco Xavier Galvão de Moura Lacerda, indiciado.

1931. A Justiça Pública, autora; Amandus Henry Quart Siloe Schoen, indiciado.

1931. A Justiça Pública, autora; Amaro Cardoso, indiciado.

1933. A Justiça Pública, autora; Amaro de Almeida Issa, indiciado.

1933. A Justiça Pública, autora; José Francisco do Monte e Sylvia Pinfildi, indiciados.

1938. A Justiça Pública, autora; Ítalo Benassi e outros, indiciados.

1939. A Justiça Pública, autora; Ariosto Palombo, vulgo João de Minas, e outros, indiciados.

1939. A Justiça Pública, autora; Francellino Ignácio da Silva, indiciado.

1939. A Justiça Pública, autora; Idalina Tairovitch, indiciada.

36 1939. A Justiça Pública, autora; Jorge José, indiciado.

1939. A Justiça Pública, autora; Maria Aurora, indiciada.

\section{Artigos da imprensa de São Paulo e do Rio de Janeiro}

Gomes de Santos. "O commércio da illusão". O Correio Paulistano. São Paulo, 24/09/1912.

"O commércio da illusão. Cartomantes e feiticeiros", O Comércio de São Paulo, São Paulo, 27/05/1913.

“O commércio da illusão", O Comércio de São Paulo, São Paulo, 19/06/1913.

"Uma cabelleira no estômago. A feitiçaria em São Paulo. Danças, rezas, drogas e cachaça!" A Capital. São Paulo, 18/11/1915.

Oscar Lopes, "Necrológio a M" Zizinha”. O Paíz, Rio de Janeiro, 5/12/1915.

\section{Bibliografia}

ARAGÃO, Luiz Tarlei de. A dessacralização do sexo e o sacrifício de mulheres. Religião e Sociedade, São Paulo, 6, 1980. 
ARAÚJO, Alceu Maynard. Alguns ritos mágicos: 'abusões', feitiçaria e medicina popular. Separata da Revista do Arquivo Municipal de São Paulo, CLXI, 1958.

BASTIDE, Roger. A macumba paulista. In: - - - Estudos afro-brasileiros. São Paulo: Perspectiva, 1983.

BORGES, Dain. 'Puffy, Ugly, Slothful and Inert': Degeneration in Brazilian Social Thought, 1880-1940. Latin American Studies, 25, 1993.

CAMARGO, Cândido Procópio F. de (Org). Católicos, protestantes, espíritas. Petrópolis: Vozes, 1973.

CÉSAR, Osório. Misticismo e loucura - contribuição para o estudo das loucuras religiosas no Brasil. São Paulo: Oficinas Gráficas do Serviço de Assistência a Psicopatas - Juquery, 1939.

CUNHA, Maria Clementina Pereira. O espelho do mundo - Juquery, a história de um asilo. Rio de Janeiro: Paz e Terra, 1984.

DAMAZIO, Sylvia F. Da elite ao povo - advento e expansão do espiritismo no Rio de Janeiro. Rio de Janeiro: Bertrand Brasil, 1994.

DIAS, Maria Odila Leite da Silva. Nas fímbrias da escravidão urbana: negras de tabuleiro e de ganho. Estudos econômicos, IPE/USP, 15, 1985.

Quotidiano e poder em São Paulo no século XIX. São Paulo: Brasiliense, 1984.

FAUSTO, Boris. Crime e cotidiano. A criminalidade em São Paulo. São Paulo: Ed. Brasiliense, 1984.

FERNANDES, Florestan. Folclore e mudança social na cidade de São Paulo. 2. Ed. Petrópolis: Vozes, 1979.

FREUD, Sigmund. Totem e tabu e outros trabalhos. Rio de Janeiro: Imago Editora, 1974. Volume XIII da Edição Standard Brasileira das Obras Completas de S. Freud.

GURVITCH, Georges. La vocation actuelle de la Sociologie - vers une sociologie différentielle. Paris: Presses Universitaires de France, 1950.

HESS, David. The Many Rooms of Spiritism in Brazil. Luso-Brazilian Review, 24 (2), 1987.

KOGURUMA, Paulo. Conflitos do imaginário - a reelaboração das práticas e crenças afro-brasileiras na metrópole do café (1890-1920). São Paulo: AnnaBlume; Fapesp, 2001.

LOMBROSO, César. Hipnotismo e mediunidade. Trad. Rio de Janeiro: Federação Espírita Brasileira (FEB), 1975. 
MACHADO, Ubiratan. Os intelectuais e o espiritismo, Rio de Janeiro: Antares; Brasília: INL; 1983.

MAGGIE, Yvonne. Medo do feitiço: relações entre magia e poder no Brasil. Rio de Janeiro: Arquivo Nacional, 1992.

MENEZES, Adolpho Bezerra de. A loucura sob um novo prisma: estudo psiquicofisiológico. Rio de Janeiro: FEB, 1983.

MONTEIRO, Duglas Teixeira. Um confronto entre Juazeiro, Canudos e Contestado. In: Fausto, Boris. História geral da civilização brasileira. O Brasil republicano. Rio de Janeiro; São Paulo: Difel, 1978, t. III, v. 2.

OLIVEIRA, Pedro Ribeiro de. Religião e dominação de classe: o caso da romanização. Religião e Sociedade, São Paulo, 6, 1980.

PINTO, Maria Inez Machado Borges. Cotidiano e sobrevivência - a vida do trabalhador pobre na cidade de São Paulo (1890-1940). São Paulo: Edusp; Fapesp, 1994.

RAGO, Margareth. Os prazeres da noite - prostituição e códigos da sexualidadade feminina em São Paulo (1890-1930). Rio de Janeiro: Paz e Terra, 1991.

RAMOS, Arthur. As práticas de feitiçaria entre os negros e os mestiços brasileiros. Archivos de Medicina legal e Identificação. Rio de Janeiro, 5 (11), 1935. O problema psychológico do curandeirismo. Brasil Médico, Rio de Janeiro, 45 (42), 1931.

Os horizontes mythicos do negro da Bahia. Archivos do Instituto Nina Rodrigues, Salvador, I (1), 1932.

RIBEIRO, Leonídio; CAMPOS, Murilo. O espiritismo no Brasil - -contribuição ao seu estudo clínico e médico-legal. São Paulo: Companhia Editora Nacional, 1931.

RODRIGUES, Raimundo Nina. O animismo fetichista dos negros bahianos. Rio de Janeiro: Civilização Brasileira, 1935.

SEVCENKO, Nicolau, Orfeu extático na metrópole - São Paulo, sociedade e cultura nos frementes anos 20. São Paulo: Companhia das Letras, 1992.

THOMAS, Keith. Religião e o declínio da magia. Trad. São Paulo: Companhia das Letras, 1991.

TRINDADE, Liana M. S. Construções míticas e História - estudo das representações simbólicas e relações sociais em São Paulo, do século XVIII à atualidade. São Paulo, tese de livre-docência, FFLCH/USP, Antropologia Social, 1991. 
WARREN, Donald. A terapia espírita no Rio de Janeiro por volta de 1900. Religião e Sociedade, São Paulo, 11 (3), 1984.

WISSENBACH, Maria Cristina Cortez. Ritos de magia e sobrevivência-práticas mágico-religiosas no Brasil, 1890-1940. São Paulo, tese de doutorado, FFLCH/USP, História, 1998.

WISSENBACH, Maria Cristina Cortez. "Da escravidão à liberdade: dimensões de uma privacidade possível". In: SEVCENKO, Nicolau (Org.) História da vida privada no Brasil. República: da Belle Époque à era do rádio. São Paulo: Cia. das Letras, 1998, vol 3.

XIDIEH, Oswaldo Elias. Um elemento ítalo-afro-brasileiro na magia mogiana. Sociologia, São Paulo, 6 (1), 1944. 